\title{
The Effect of Waste Fodder Potato Proteins on the Mechanical Properties of Carboxylated Acrylonitrile-Butadiene Rubber
}

\author{
Mirosława Prochoń, Anita Przepiórkowska, and Yves-Herve Tshela Ntumba \\ Institute of Polymers and Dye Technology, Technical University of Lodz, Stefanowskiego Street 12/16, 90-924 Lodz, Poland \\ Correspondence should be addressed to Mirosława Prochoń, miroslawa.prochon@p.lodz.pl
}

Received 23 January 2012; Accepted 20 February 2012

Academic Editors: B. Hazer and C. T. Ratnam

Copyright ( $) 2012$ Mirosława Prochon et al. This is an open access article distributed under the Creative Commons Attribution License, which permits unrestricted use, distribution, and reproduction in any medium, provided the original work is properly cited.

\begin{abstract}
The current investigation treats about the influence of waste fodder potato proteins (WFPP) recovered from the starch industry on the mechanical-properties of carboxylated acrylonitrile-butadiene rubber (XNBR). WFPP were characterized and used as a filler of the above mentioned XNBR rubber without or after blending with zinc oxide. The obtained rubber compounds were cured, and mechanical properties such as tensile strength, hardness, and cross-linking density were investigated. It was found that the introduction of WFPP previously blended with zinc oxide into rubber compound increases the cross-linking density of the obtained composites, compared with the vulcanizate without protein, which in turn increases the mechanical properties of the obtained vulcanizates. That occurs thanks to the formation of ion nodes, as testified by equilibrium swelling. The introduction of WFPP into the elastomer matrix also increases the susceptibility of the elastomer to biodecomposition.
\end{abstract}

\section{Introduction}

Reviewing the literature, it is easy to notice that biodecomposable rubber materials are not produced in large quantity. One of the biggest problems of the modern industry, which is dominated by polymers, is the excessive production of waste. That waste needs to be eliminated or, at least, reutilized. The aim of this paper is to obtain a new functional rubber compound with good properties which is susceptible to undergo biodecomposition in natural environment thanks to the introduction of waste potato proteins into an elastomeric matrix. The obtained rubber compound fulfils the two aims mentioned above: it reutilizes waste (potato proteins) and it is biodecomposable. As a result, the material can be easily eliminated from the environment.

At this point, it is important to define the meaning of biodecomposition. Biodecomposition, unlike biodegradation, does not lead to complete degradation into water, carbon dioxide, and humus. In this paper, biodecomposition refers to the decomposition of the protein filler which provides for degradation of the structure of the material, resulting in worse mechanical properties. The material loses its functionality and can more easily be decomposed into pieces under the influence of mechanical and natural factors.
The proteins contained in potatoes are a byproduct in starch production and are considered as a waste, in quantities of about 200 thousand tons per year. Usually, these proteins are used as a component of fodder mixtures for animals, simultaneously replacing animal proteins.

Potato proteins are a rich source of nutritious components. Therefore their total recovery seems to be justified. Some like Kudo and others [1-3] noticed that the peptides isolated from potato protein hydrolyzate have antioxidant properties, which are unusually profitable if used as a potential addition to food.

Løkra et al. [4] subjected potato sewage to enzymatic hydrolysis obtaining surfactants. The composition of potato sewage is $20-25 \%$ proteins and amino acids, $15 \%$ sugar and $20 \%$ mineral components, $14 \%$ organic acids, and other compounds such as phenolic compounds. Many researchers indicate the antioxidant properties of potato protein hydrolyzates [2-5]. Literature overview reported that waste potato proteins found application in the production of bioethanol from potato cell sap [6-8].

The strengthening properties of plant proteins associated with polysaccharides on polymeric composites are also reported in literature. Jong noticed the profitable influence 
of soybean protein and polysaccharides as fillers on the mechanical properties of butadiene-styrene rubber [9].

The present investigation treats about the waste from potato industry, which will allow obtaining materials with good mechanical proprieties, susceptible to undergo biodecomposition after the period of use.

\section{Material}

Carboxylated acrylonitrile-butadiene rubber XNBR (Krynac X7.50) was obtained from Bayer AG (6.7\% of carboxylic groups). It was chosen because of its better properties in comparison with conventional nitrile rubber NBR (higher abrasion resistance, modulus, and tensile strength). On the other hand, taking under consideration that the filler is a protein (i.e., it is polar), a polar matrix should be used since the interaction between the matrix and the filler is very important. Carboxylated groups in XNBR are susceptible to interact with WFPP as well as with zinc oxide, used as an activator in the vulcanization process, providing for the formation of additional ionic cross-links as reported by Mandal and Aggarwal [10,11].

The waste fodder potato protein (WFPP) from Food Company PEPEES S. A. in Łomża (Poland) was obtained by thermal-acidic processing of the potato cell sap as a grey powder. The WFPP powder was sifted through a sieve with $0,1 \mathrm{~mm}$ mesh and then characterized.

Stearin was also added as a plasticizer, alongside with sulphur and MBTS as a cross-link agent. Zinc oxide is an accelerator of the cross-linking process, but as it will be shown, it can also fulfil other functions as reducing the particle size of the filler or acting as a cross-link agent.

\section{Characterization}

The characteristic of WFPP showed that the particle size of the studied object is in the range from 208 to $745 \mathrm{~nm}(100 \%$ of particles) and the isoelectric point is about $\mathrm{pH}=2,8$. The Infrared analysis FTIR has shown that the deforming vibration of I and II amide and methylene group linked to the peptide bond ranged between $1649 \mathrm{~cm}^{-1}$ and $1433 \mathrm{~cm}^{-1}$. After characterization, the WFPP was applied as filler in rubber compounds.

The WFPP was added in two different forms: unblended or blended with zinc oxide. It has been shown that blending protein with zinc oxide provides for a decrease of particle size, which in turn provides for a better dispersion of the protein in the elastomeric matrix [12]. The blend was prepared by manually mixing powdered WPFF with zinc oxide in a 1 to 1 ratio.

\section{Methods}

(i) Rubber compounds were prepared using a mixing mill at roll temperature of $30^{\circ} \mathrm{C}$ and friction of $1: 1,5$. Vulcanization of the compounds was carried out in a mould press at $150^{\circ} \mathrm{C}$. (ii) The rubber compounds were vulcanized in steel moulds placed between electrically heated press shelves at temperature $150^{\circ} \mathrm{C}$, under pressure $15 \mathrm{MPa}$ and during a time $\tau_{90}$ according to the standard PNISO 3417: 1994 (vulcameter with an oscillating rotor WG-02 ZACH METALCHEM).

(iii) The cross-linking density was determined from equilibrium swelling in the following solvents: toluene, toluene with ammonia vapour, and water (in accordance with the standard PN-ISO 817:2001/ ap1:2002). The density of the rubber was measured according to standard PN-ISO $2781+\mathrm{AC} 1: 1996$, and the density of lattice was found using Flory and Rehner's equation [13].

(iv) The tensile strength of the vulcanizates was determined by means of a Zwick 1442 tensile testing machine according to the standard PN ISO $37: 1998$.

(v) The resistance to thermal ageing was investigated according to the standard PN-88/C-04207, using the relation:

$$
\mathrm{S}=\frac{\left[\mathrm{Ts}_{1} * \mathrm{~Eb}_{1}\right]}{\left[\mathrm{Ts}_{2} * \mathrm{~Eb}_{2}\right]},
$$

where S: aging coefficient, $\mathrm{Ts}_{1}$ : tensile strength and $\mathrm{Eb}_{1}$ : elongation at break after thermal ageing, $\mathrm{Ts}_{2}$ : tensile strength, and $\mathrm{Eb}_{2}$ : elongation at break before thermal ageing.

(vi) The FTIR spectroscopy (BIO RAD FTS 175C) of vulcanizates was performed by transmission method. Samples in the form of thin films were prepared by pressing a rubber compound under a pressure of $15 \mathrm{MPa}$.

(vii) The hardness was determined by Shore's method according to PN-80C-04238 using a Zwick/Roell electronic hardness tester, type $\mathrm{A}$, under pressure with a force of $12,5 \mathrm{~N}$.

(viii) The biodegradation test of the rubber was carried out in soil (Soil Tests);samples were placed in an active compost universal soil $(10 \mathrm{~cm})$ and incubated at a temperature of $30^{\circ} \mathrm{C}$ and humidity $80 \% \mathrm{RH}$. After 30 days of incubation, the appearance of samples was evaluated using microscopy. Tests were carried out according to the standard PN-EN ISO 846, December 2002.

\section{Results and Discussion}

The influence of WFPP on carboxylated nitrile rubber XNBR cross-linking process has been examined. Mixing WPFF with $\mathrm{ZnO}$ provides for a decrease of particle size. This decrease can be attributed to the formation of clusters, where the protein or peptide chains are surrounded by zinc oxide molecules, forming a closed shell and preventing the protein chains from agglomeration. Those interactions are probably ionic as between zinc cation and XNBR carboxylic groups [10] or could result from hydrogen bonds or coordinative 
TABLE 1: Composition of the rubber compounds and the effect of WPFF on the curing characteristics and mechanical properties of rubber compounds and vulcanizates of XNBR.

\begin{tabular}{|c|c|c|c|}
\hline \multirow[b]{2}{*}{ Content } & \multicolumn{3}{|c|}{ XNBR (Krynac X7.50) } \\
\hline & XNBR & WFPP/XNBR & $\mathrm{WFPP}+\mathrm{ZnO} / \mathrm{XNBR}$ \\
\hline WFPP [phr] & - & 5 & - \\
\hline $\mathrm{WFPP}+\mathrm{ZnO}[\mathrm{phr}]$ & - & - & $5+5$ \\
\hline $\mathrm{ZnO}[\mathrm{phr}]$ & 5 & 5 & - \\
\hline \multicolumn{4}{|c|}{$\begin{array}{l}\text { Other ingredients: Carboxylated acrylonitrile-butadiene rubber XNBR (Krynac X7.50 carboxylated nitrile } \\
\text { rubber)-100phr, sulphur-2,5phr, dibenzothiazyl disulphide (MBTS)-1,5phr, Stearin-2phr. }\end{array}$} \\
\hline$L_{\min }^{*}[\mathrm{dNm}]$ & 10,10 & 12,10 & 13,00 \\
\hline$\Delta L[\mathrm{dNm}]$ & 94,60 & 98,40 & 98,20 \\
\hline$\tau_{90}[\mathrm{~min}]$ & 30 & 21 & 19 \\
\hline$a_{f}[-]$ & - & 0,80 & 0,76 \\
\hline$\nu_{\mathrm{T}}\left[10^{4} \mathrm{~mol} / \mathrm{dm}^{3}\right]$ & 2,6745 & 2,6898 & 2,81 \\
\hline$/ \mathrm{NH}_{3}\left[10^{4} \mathrm{~mol} / \mathrm{dm}^{3}\right]$ & 1,5623 & 1,4412 & 1,35 \\
\hline$\Delta v \quad \Delta V_{\mathrm{NH}_{3}}=V_{\mathrm{T}}-V_{\mathrm{T} / \mathrm{NH}_{3}}\left[\mathrm{~mol} / \mathrm{dm}^{3}\right]$ & 1,11 & 1,25 & 1,46 \\
\hline $\mathbf{A}_{1} \quad \mathrm{~A}_{1}=\left(\Delta V_{\mathrm{NH}_{3} / \mathrm{VT}}\right) * 100 \%[\%]$ & 41,58 & 46,47 & 51,95 \\
\hline $\mathrm{S}_{100}[\mathrm{MPa}]$ & 2,22 & 2,25 & 2,40 \\
\hline $\mathrm{S}_{200}[\mathrm{MPa}]$ & 3,72 & 3,36 & 3,79 \\
\hline $\mathrm{S}_{300}[\mathrm{MPa}]$ & 7,19 & 5,59 & 6,67 \\
\hline Ts $[\mathrm{MPa}]$ & 10,17 & 10,38 & 13,76 \\
\hline $\mathrm{Eb}[\%]$ & 334 & 385 & 315 \\
\hline Thermal ageing S [MPa $* \% / \mathrm{MPa} * \%]$ & 0,56 & 0,76 & 0,96 \\
\hline Qw-equilibrium swelling in water $[\mathrm{mg} / \mathrm{mg}]$ & 0,068 & 0,087 & 0,090 \\
\hline \multicolumn{4}{|l|}{ Biodecompisition } \\
\hline $\mathrm{TS}[\mathrm{MPa}]$ & 10,10 & 10,30 & 11,60 \\
\hline $\mathrm{Eb}[\%]$ & 313 & 299 & 305 \\
\hline Hardness A [ $\left.{ }^{\circ} \mathrm{Sh}\right]$ & 58 & 61 & 59 \\
\hline Hardness after biodecomposition [ $\left.{ }^{\circ} \mathrm{Sh}\right]$ & 57 & 56 & 59 \\
\hline
\end{tabular}

interactions between zinc oxide and amine $\left(-\mathrm{NH}-,-\mathrm{NH}_{2}\right)$ as well as hydroxyl $(-\mathrm{OH})$ groups. Therefore the protein was added to the rubber compounds separately or after mixing with $\mathrm{ZnO}$, because, as shown, it decreases the size of WFPP particles from $526 \mathrm{~nm}$ to $417 \mathrm{~nm}$.

Table 1 shows the compositions of rubber compounds, as well as the curing characteristics and mechanical proprieties of carboxylated nitrile rubber filled with WFPP. As the data given in Table 1 show, the smallest minimal torque moment $L_{\min }$ (the smallest viscosity) characterizes the mixture without filler, but it has the smallest value of $\Delta L$. Independently from how the components of XNBR rubber compounds were prepared, the introduction of the WFPP caused a growth of the viscosity of mixtures. The compounds with waste as filler are characterized by higher value of $\Delta L$ in comparison with XNBR compounds without waste. The curing time $\left(\tau_{90}\right)$ undergoes shortening for WFPP/XNBR and also for WFPP + $\mathrm{ZnO} / \mathrm{XNBR}$.

WFPP are an active filler, which can induce the formation of a common macromolecular network. Therefore their addition should improve mechanical parameters of the obtained vulcanizates. The particle size of the filler in the range from 0,2 to $0,7 \mu \mathrm{m}$ is a clear evidence.
Practically for all protein-elastomer composites we noticed an increase of the cross-linking density, determined from equilibrium swelling in toluene $\left(\nu_{T}\right)$. This is caused by the formation of ionic bonds in the polymer matrix. The fraction of formed ionic bonds in polymer matrix decomposing under the influence of ammonia $\left(A_{1}\right)$ for XNBR composites with natural filler increases from 10 to $25 \%$ in comparison with XNBR without filler. That probably occurs as a result of the formation of connections between polar and nonpolar fragments of filler particles and the elastomeric matrix. One can also assume that terminal amino groups in protein can interact with carboxylic groups in the elastomer forming new amide bonds. On the other hand, interactions between zinc cation and carboxylic groups can occur with the participation of carboxylic groups from both elastomer and protein. Those interactions result in better dispersion of the filler and in the improvement of mechanical properties.

Indeed, the obtained active fillers improve the value of tensile strength Ts and elongation at break Eb. The composite filled with WFPP blended with zinc oxide has a higher value of tensile strength Ts.

Table 1 also presents results of resistance to thermal ageing. The value of aging coefficient $(S)$ clearly increases when 


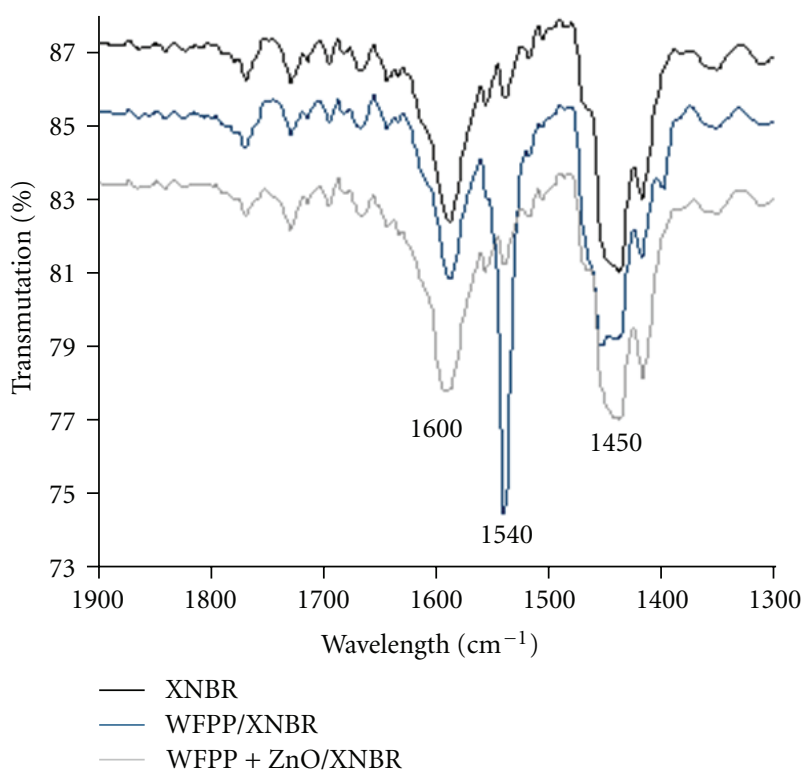

FIGURE 1: The FTIR spectrum of carboxylated nitrile rubber vulcanizates.

biopolymers are introduced into the elastomeric matrix. This coefficient testifies about better antioxidative proprieties of materials with protein addition. In result of aging process, different groups are formed. Thanks to them, materials can work in higher temperatures keeping unchanged mechanical parameters.

FTIR analysis of materials unfilled and filled with protein is shown on Figure 1.

Comparing spectra of filled and unfilled vulcanizates, differences resulting from the formation of common structural network between protein and polymer can be noticed.

For protein-elastomer materials we observed the growth of water affinity (Table 1). To a large extent, responsible for this is the structure of the protein. The addition of the proteins into the elastomer facilitates the penetration of water molecules into its structure, resulting in the hydratation and swelling of the obtained composite, making the enzyme transport easier and the biodecomposition quicker after the time of use of the material.

The influence of WFPP on the mechanical proprieties of XNBR vulcanizates before and after 30-day incubation in universal soil is featured in Table 1, and samples are represented in Figure 2.

Beyond any doubt, applied fillers in both forms (WFPP/ $\mathrm{XNBR}$ and WFPP $+\mathrm{ZnO} / \mathrm{XNBR}$ ) increase the susceptibility of the elastomer to biodecomposition. The decreasing values of tensile strength Ts testify about changes, resulting from the action of microorganisms. The WFPP $+\mathrm{ZnO} / \mathrm{XNBR}$ composite is the most susceptible to microbiological influence, because its tensile strength decreases about 19\%. We observed that the introduction of WFPP to the XNBR rubber caused the growth of hardness (Table 1). However, after the soil test, the parameter of hardness decreased and the samples became more elastic. The changes of mechanical and hardness proprieties, as well as the visible surface changes:

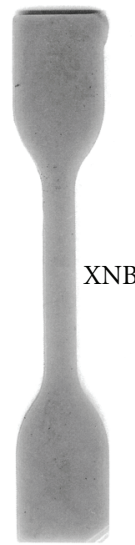

Before

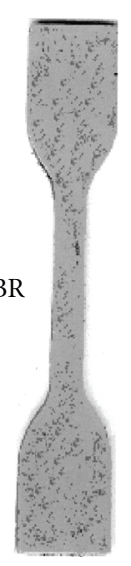

After

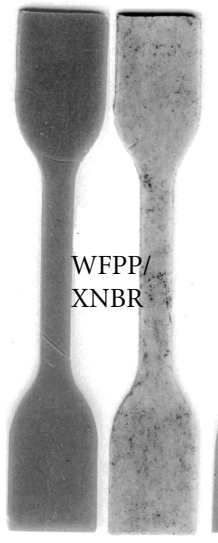

Before After

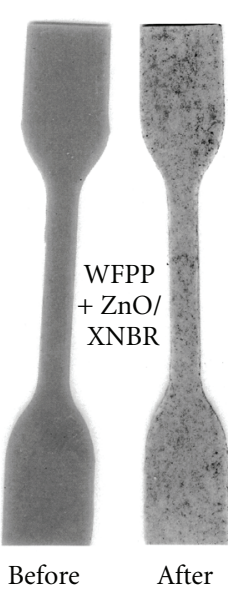

Figure 2: The samples before and after 30-day incubation in universal soil.

the fading out and roughness (Figure 2), indicate the absence of the mushroom-static effect and also the susceptibility to the influence of soil microorganisms with proteolytic properties on the studied materials.

\section{Conclusions}

Biodegradable protein-elastomer materials with good mechanical proprieties were obtained, thanks to the introduction of a biopolymer as filler-the WFPP. The introduction of WFPP blended with zinc oxide in the elastomer matrix influences material by improving its tensile strength and hardness in comparison with composite without protein. The introduction of the WFPP into rubber has an effect on the increase of the thermal aging coefficient of vulcanizates. In soil tests, the composites are characterized by a larger susceptibility to environmental biotic factors, than the composite without protein filler (XNBR). That tendency to biodecomposition is also testified by larger absorbency of water through filled materials. Some may observe that the difference in tensile strength, especially for WFPP/XNBR, is very small, but for the WFPP $+\mathrm{ZnO} / \mathrm{XNBR}$ compound the difference is bigger after only 30 -day incubation. Taking into account this fact, incubation in a longer period of time should give better results in both cases, leading to sharper deterioration of mechanical properties of the obtained material.

\section{Acknowledgment}

This paper was sponsored by the European Project: "The use of biomass for the production of environmental friendly polymeric materials" no. POIG 01.01.02-10-123/09.

\section{References}

[1] K. Kudo, S. Onodera, Y. Takeda, N. Benkeblia, and N. Shiomi, "Antioxidative activities of some peptides isolated from hydrolyzed potato protein extract," Journal of Functional Foods, vol. 1, no. 2, pp. 170-176, 2009. 
[2] A. Moure, H. Domínguez, and J. C. Parajó, "Antioxidant activity of fractions from acid hydrolysates of almond shells," Journal of Food Process Engineering, vol. 31, no. 6, pp. 817-832, 2008.

[3] Y. Cheng, Y. L. Xiong, and J. Chen, "Antioxidant and emulsifying properties of potato protein hydrolysate in soybean oil-inwater emulsions," Food Chemistry, vol. 120, no. 1, pp. 101-108, 2010.

[4] S. Løkra, R. B. Schüller, B. Egelandsdal, B. Engebretsen, and K. O. Strætkvern, "Comparison of composition, enzyme activity and selected functional properties of potato proteins isolated from potato juice with two different expanded bed resins," LWT-Food Science and Technology, vol. 42, no. 4, pp. 906913, 2009.

[5] G. A. van Koningsveld, Physico-chemical and functional properties of potato proteins, Thesis Dissertation, Wageningen University, 2001.

[6] M. Suzuki, S. Sakai, A. Ikegaya et al., "Production of ethanol from food wastes," Shizuoka-ken Kogyo Gijutsu Kenkyusho Kenkyu Hokoku, vol. 2, pp. 82-83, 2009.

[7] G. Yue, Y. Zhang, Q. Liu et al., "Method for preparing ethanol by adopting yam materials," Chinese Patent 101586124 A, 2009.

[8] X. Hao, Y. Zhang, L. Dieng, H. Lin, D. Wang, and G. Wu, "Method for preparing ethanol from tuber crops raw material," Chinese Patent 101487024, 2009.

[9] L. Jong, "Effect of soy protein concentrate in elastomer composites," Composites Part A, vol. 37, no. 3, pp. 438-446, 2006.

[10] U. K. Mandal, "Ionic elastomer based on carboxylated nitrile rubber: infrared spectral analysis," Polymer International, vol. 49, no. 12, pp. 1653-1657, 2000.

[11] U. K. Mandal and S. Aggarwal, "Studies on rubber-filler interaction in carboxylated nitrile rubber through microhardness measurement," Polymer Testing, vol. 20, no. 3, pp. 305-311, 2001.

[12] M. Prochoń, A. Przepiórkowska, and M. Zaborski, "Keratin as a filler for carboxylated acrylonitrile-butadiene rubber XNBR," Journal of Applied Polymer Science, vol. 106, no. 6, pp. 3674-3687, 2007.

[13] P. J. Flory and J. Rehner, "Statistical mechanics of crosslinked polymer networks II. Swelling," The Journal of Chemical Physics, vol. 11, no. 11, pp. 521-526, 1943. 

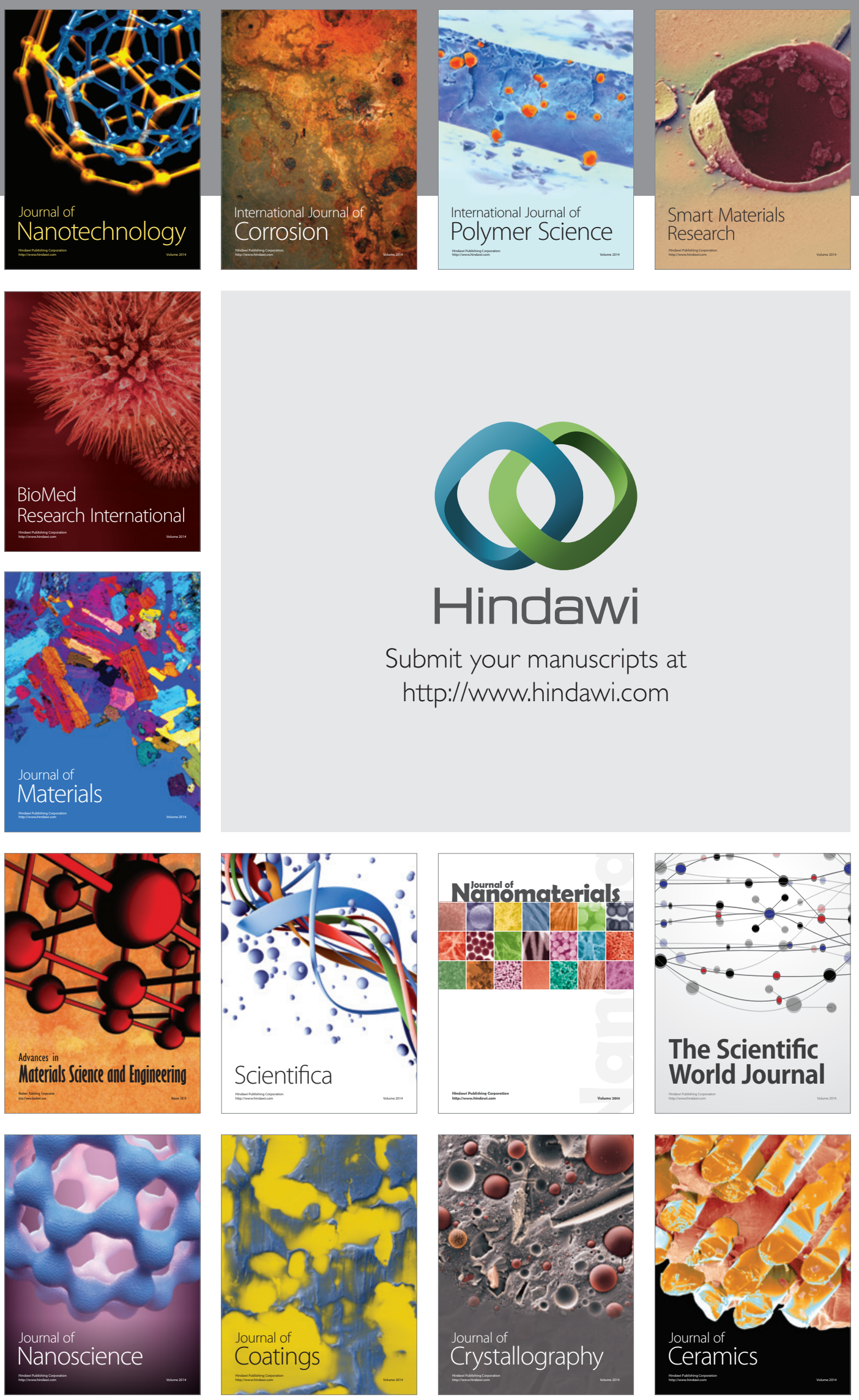

The Scientific World Journal

Submit your manuscripts at

http://www.hindawi.com

\section{World Journal}

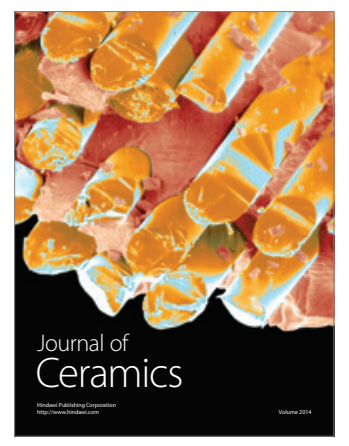

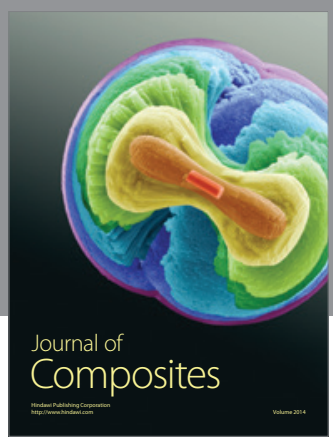
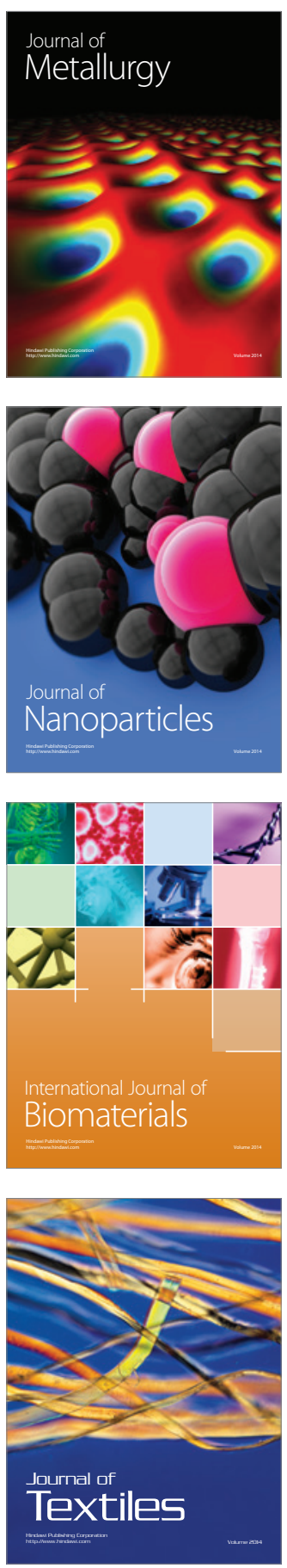